\title{
Wind-induced changes in the dynamics of fluorescent organic matter in the coastal NW Mediterranean
}

Fran L. Aparicio ${ }^{1}$, Mar Nieto-Cid $^{2}$, Eva Calvo $^{1}$, Carles Pelejero ${ }^{1,3}$, Àngel López-Sanz ${ }^{1}$, Josep Pascual $^{4}$, Jordi Salat ${ }^{1}$, Elvia D. Sánchez-Pérez ${ }^{5}$, Josep M. Gasol ${ }^{1}$, Cèlia Marrasé ${ }^{1}$.

${ }^{1}$ ICM-CSIC, Institut de Ciències del Mar, Passeig Marítim de la Barceloneta 37-49, 08003 Barcelona, Catalunya, Spain

${ }^{2}$ IIM-CSIC, Instituto de Investigaciones Marinas, C/ Eduardo Cabello 6, 36208 Vigo, Spain

${ }^{3}$ ICREA, Institució Catalana de Recerca i Estudis Avançats, Passeig Lluís Companys 23, 08010 Barcelona, Catalunya, Spain

${ }^{4}$ Estació Meteorològica de L'Estartit, Girona, Catalunya, Spain

${ }^{5}$ Sorbonne Universités, UPMC Univ. Paris 06, UMR 7621, Laboratoire d'Océanographie Microbienne, Observatoire Océanologique, F-66650 Banyuls/mer, France

\section{Abstract}

Marine biogeochemistry dynamics in coastal marine areas is strongly influenced by episodic events such as rain, intense winds, river discharges and anthropogenic activities. In this study, we evaluated the importance of these forcing events on modulating seasonal changes in the marine biogeochemistry of the northwestern coast of the Mediterranean Sea, based on data gathered in a fixed coastal sampling station in the area. A 4-year (2011-2014) monthly sampling was performed to examine the time variability of several oceanographic variables: seawater temperature, salinity, inorganic nutrient concentrations $\left(\mathrm{NO}_{3}{ }^{-}, \mathrm{PO}_{4}{ }^{3-}\right.$ and $\left.\mathrm{SiO}_{2}\right)$, chlorophyll a $(\mathrm{Chl}$ a), dissolved organic carbon (DOC) and fluorescent dissolved organic matter (FDOM). These variables were monitored at four depths: $0.5 \mathrm{~m}, 20 \mathrm{~m}, 50 \mathrm{~m}$ and $80 \mathrm{~m}$. FDOM dynamics was predominantly influenced by upwelling events and mixing processes, driven by strong and characteristic wind episodes. SW wind episodes favored the upwelling of deeper and denser waters into the shallower shelf, providing a surplus of autochthonous humic-like material and inorganic nutrients, whereas northerlies favored the homogenization of the whole shelf water column by cooling and evaporation. These different wind-induced processes (deep water intrusion or mixing), reported along the four sampled years, determined a high interannual environmental variability in comparison with other Mediterranean sampling sites. 


\section{Keywords}

NW Mediterranean; wind events; salinity; inorganic nutrients; DOC; FDOM

\section{1.- Introduction}

The Mediterranean Sea is a large semi-enclosed basin with complex water circulation patterns. From a biogeochemical perspective, it is defined as a lownutrient, low-chlorophyll system (Durrieu de Madron et al., 2011 and references therein; Santinelli, 2015). Due to its geographic characteristics, the Mediterranean Sea is a concentration basin (Hopkins, 1978) prone to high evaporation, unequal precipitation rates among basins and relevant mesoscale activity with regional and local impacts (Robinson et al., 2001).

In the northwestern Mediterranean Sea, the upper water column circulation is characterized by the presence of the Liguro-Provenço-Catalan or Northern current, a quasi-permanent current that flows southward from the Gulf of Lions towards the Gulf of Valencia, along the continental slope (López-García, 1994). The dominant winds in this region blow from the northern sector (Mistral (NW), Tramuntana (N) and Gregal (NE); Salat 1996; Guadayol et al., 2006 and references therein). These winds are particularly strong and persistent during winter, bringing cold and dry continental air over the warmer ocean and thus generating intense air-sea latent and sensible heat exchanges, leading to the cooling of surface waters and evaporation (Salat, 1996; Flamant et al., 2003; Millot and Taupier-Letage, 2005). The consequent loss of buoyancy at surface from the decrease in temperature and increase of salinity induces convective mixing and a vertical homogenization of the water column on the shelf (Salat and Font, 1987).

Different studies conducted at several oceanic sampling stations in the NW Mediterranean have considered the action of winds as drivers for the mixing processes present in the water column. The work of De Fommervault et al. (2015) followed the temporal variability of inorganic nutrients between 1991 and 2001 at the DYFAMED station (Ligurian Sea). With a total depth of $2300 \mathrm{~m}$, this oceanic site is characterized by very marked thermoclines that during summer impede the regeneration of nutrients towards the surface layers. 
Conversely, the less frequent and persistent winds from the southern sectors, blowing northward parallel to the coastline, favor an offshore Ekman transport that induces coastal upwelling processes of deeper waters towards the shallower layers of the shelf (Millot, 1979; Millot and Taupier-Letage, 2005; VilaReixach et al., 2012). The study of Para et al. (2010) conducted in the Gulf of Lions (NW Mediterranean) at the SOFCOM oceanic station reported mixing phenomena of the entire water column in winter (60 m deep) under 3 to 12 consecutive days of Mistral winds.

During summer, winds are usually weaker than in other seasons. Yet, the variability found in the inner-shelf of the Catalan Sea is predominantly driven by storm-induced fluctuations and forcing mechanisms acting primarily at seasonal scales, since the Mediterranean is a microtidal environment (Grifoll et al., 2013). In terms of continental climatology, the NW Mediterranean region is characterized by a long dry summer season with stable atmospheric conditions and mild temperatures in winter, with sporadic rain episodes distributed throughout the year, but mostly during spring and autumn (Colacino, 1992; Bolaños et al., 2009). The inputs of freshwater associated to these precipitation episodes might constitute a relevant contribution of dissolved organic matter (DOM) to marine ecosystems.

Marine DOM can be autochthonous (as, for example, the by-products of marine organisms metabolism derived from phytoplankton and macroalgal extracellular release, cell lysis or particulate organic matter dissolution into DOM; RomeraCastillo et al., 2011b; Wada et al., 2015; Turner, 2015), or allochthonous (mainly from terrestrial origin, as for example leachates from terrestrial plants, wetland drainage and aerosol deposition; Coble, 2007; Murphy et al., 2008; Pey et al., 2010; Sánchez-Pérez et al., 2016), which includes a high diversity of molecular compounds of varying lability. The study of the DOM distribution and transformations in marine systems, along with its role in the carbon cycle, has been in the spotlight during the last two decades because it constitutes one of the greatest reservoirs of organic carbon on Earth (Hansell et al., 2009). 
The biogeochemical carbon cycle will be affected in the coming decades by anthropogenic-derived activities such as global warming. In this context, it becomes necessary to gain knowledge on the Earth's natural mechanisms to alleviate the atmosphere of the greenhouse gases excess. The 'microbial carbon pump' (MCP; Jiao et al., 2010) is one of the main mechanisms employed by the oceans to trap the $\mathrm{CO}_{2}$ accumulated in the atmosphere. The MCP is composed by a complex set of microbial processes that enables the formation of highly recalcitrant DOM and therefore facilitates the accumulation of carbon in the deep waters.

A portion of this DOM is capable of absorbing light at ultraviolet and visible wavelengths, named chromophoric dissolved organic matter (CDOM), and a sub-fraction of this pool, known as fluorescent dissolved organic matter (FDOM), can also re-emit this absorbed light as fluorescent energy (Coble, 1996). The different DOM optical properties are useful tracers of the nature, origin and possible fate of the DOM in aquatic ecosystems. Thus, some groups of compounds can be detected by its characteristic fluorescence signal, as for example the humic-like substances (Coble, 1996). The fluorescence of the humic-like fraction of DOM usually presents a shift to long wavelengths (Coble, 1996), which is mainly associated with higher aromaticity. The complexity in their molecular structure confers recalcitrant characteristics to the humic-like compounds. The more recalcitrant a compound is, the more difficult it is to be remineralized by organisms (Hansell et al., 2009), facilitating its accumulation and trapping $\mathrm{CO}_{2}$ on its organic form in the ocean for long time scales (Chen and Bada, 1994; Jiao et al., 2010). The presence of fluorescent humic-like material in marine coastal systems has been related mainly to allochthonous inputs (Nieto-Cid et al., 2005; Romera-Castillo et al., 2011a; Sánchez-Pérez et al., 2016), but also to microbial respiration processes (Nieto-Cid et al., 2006; Romera-Castillo et al., 2010). In 2014, Organelli et al. also identified DOM from heterotrophic bacteria at the oceanic BOUSSOLE site (Ligurian Sea).

In the particular case of the Mediterranean coastal areas, the study of humiclike compounds in the monitoring programs of this region has shown different temporal patterns that span from weak to strong seasonality (SOFCOM station, 
Para et al., 2010; Blanes Bay Microbial Observatory -BBMO-, Romera-Castillo et al., 2013). The physical forcing factors tend to have an episodic occurrence (e.g. wind events and rain episodes), adding variability to the main seasonal pattern. These factors may distort the annual seasonal predictability, particularly in coastal areas (Cloern and Jassby, 2008), and for that reason we aimed to analyze the effects of these episodic factors on the seasonality of the humic-like compounds.

In this study, we examine, along four years (2011 to 2014), the seasonal cycle of DOM in a NW Mediterranean coastal site (Figure 1), L'Estartit Oceanographic Station (EOS) where temperature and salinity data been recorded since 1974 , we aim to assess the links between environmental drivers and biogeochemical parameters in the NW Mediterranean under seasonal cycles subjected to intermittent external forcing factors. In this specific site, a high interannual environmental variability was already observed in the early studies (Margalef, 1969), which has been consistently confirmed over the following decades and until the present thanks to the ongoing meteorological and oceanographic timeseries at EOS (samples taken by Josep Pascual; e.g. Salat and Pascual, 2002). Other coastal NW Mediterranean time-series with data on seasonal DOM variability were limited to just one depth: Tedetti et al. (2012) in the bay of Marseille (SE France), Vila-Reixach et al. (2012) and Romera-Castillo et al. (2013) in the (BBMO) and Sánchez-Pérez (2015) in the bay of Banyuls-sur-mer (SE France). In the present work, we studied the DOM dynamics through the whole water column (until a depth of $80 \mathrm{~m}$ ) during a 4-year period in the context of the forcing factors affecting the hydrodynamics in the Mediterranean coastal areas, with insight of those acting at a local scale (wind and rainfall episodes). With this in mind, we characterized the dynamics and the possible export to deeper layers of FDOM material at EOS, and the role of this NW Mediterranean coastal station in the global processes involving the MCP.

\section{2. - Methodology}

\section{1. - Location of the sampling point}

L'Estartit Oceanographic Station (EOS) is located in the NW Mediterranean Sea $(42.05 \mathrm{~N}, 3.25 \mathrm{E}$, Figure 1), $2 \mathrm{~km}$ off the Medes Islands and $3.2 \mathrm{~km}$ off the main 
coast. The water depth at the sampling point is $\sim 90 \mathrm{~m}$. EOS presents several remarkable features: i) it is affected by an extreme variability of the wind regime throughout the year (Bolaños et al., 2009); and ii) it is near an area catalogued as a Specially Protected Area of Mediterranean Importance (SPAMI zone).

Seawater samples were taken monthly from January 2011 to December 2014, collected with $5 \mathrm{~L}$ Niskin bottles at four depths: $0.5 \mathrm{~m}$ (surface), $20 \mathrm{~m}, 50 \mathrm{~m}$ and $80 \mathrm{~m}$. Once on board, the water was filtered through acid-cleaned $200 \mu \mathrm{m}$ nylon mesh to remove large planktonic organisms and the samples were kept in $8 \mathrm{~L}$ acid-cleaned polyethylene carboys, covered with black plastic bags to avoid photo-degradation. All the material used was rinsed with the water sample before the analyses. The samples were carried to the laboratory in Barcelona and analyzed within $4 \mathrm{~h}$. A few data gaps in this time series were due to adverse weather conditions.

\section{2. - Monitored variables}

Monthly salinity and temperature vertical profiles were taken in situ with a CTD probe (model SD204, SAIV A/S), except from July to September 2014 when the CTD was inoperative. Additional intermediate temperature data were obtained roughly three times per week using calibrated Richter and Weise reversing thermometers at 0.5 (surface), 20, 35, 50, 65 and 80 m deep, approximately.

At the laboratory, chlorophyll a ( $\mathrm{Chl} \mathrm{a)}$ was measured by filtering $100 \mathrm{~mL}$ of seawater through a glass fiber filter (GF/F Whatman) and analyzed following the methodology used by Yentsch and Menzel (1963). The filter was immersed in acetone solution $(90 \%, v / v)$ in the dark at $4{ }^{\circ} \mathrm{C}$ for $24 \mathrm{~h}$. Fluorescence at $670 \mathrm{~nm}$ was measured with a fluorometer (Turner Designs).

Samples for inorganic nutrients, nitrate $\left(\mathrm{NO}_{3}{ }^{-}\right)$, phosphate $\left(\mathrm{PO}_{4}{ }^{3-}\right)$ and silicate $\left(\mathrm{SiO}_{2}\right)$, were stored in $15 \mathrm{~mL}$ acid-cleaned polyethylene vials and kept frozen ($20^{\circ} \mathrm{C}$ ) until analysis. Concentrations were determined by standard continuous flow analysis with colorimetric detection (Hansen \& Grasshoff 1983) using a Bran + Luebbe autoanalyser. Precisions were $\pm 0.01 \mu \mathrm{mol} \mathrm{kg}^{-1} \mathrm{NO}_{3}^{-}, \pm 0.02 \mu \mathrm{mol}$ $\mathrm{kg}^{-1} \mathrm{PO}_{4}{ }^{3-}$, and $\pm 0.01 \mu \mathrm{mol} \mathrm{kg}{ }^{-1} \mathrm{SiO}_{2}$. 
DOC samples were prefiltered under reduced pressure through precombusted Whatman glass fiber filters (GF/F) and collected in $10 \mathrm{~mL}$ precombusted (450 ${ }^{\circ} \mathrm{C}, 24 \mathrm{~h}$ ) glass ampoules. After acidification to $\mathrm{pH}<2$ with $50 \mu \mathrm{L}$ of $25 \% \mathrm{H}_{3} \mathrm{PO}_{4}$, the ampoules were heat-sealed and stored in the dark at $4{ }^{\circ} \mathrm{C}$ until analysis. Measurements were carried out using a Shimadzu TOC-CSV organic carbon analyzer. Three to five injections of $150 \mu \mathrm{L}$ were performed per replicate. The DOC concentration in each replicate was calculated by subtracting a Milli-Q blank and dividing by the slope of a daily standard curve made from potassium hydrogen phthalate. All samples were checked against reference material (MRC Batch-13 Lot //08-13) from Hansell Laboratory (University of Miami, RSMAS).

The fluorescent properties of DOM were measured using a Perkin Elmer LS55 luminescence spectrometer equipped with a xenon discharge lamp equivalent

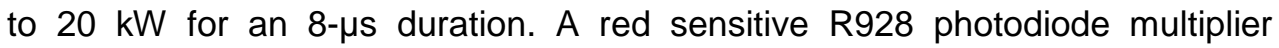
worked as a reference detector. Single measurements and emission excitation matrices (EEMs) were performed in a $1 \mathrm{~cm}$ acid-cleaned quartz fluorescence cell at a constant room temperature. Fluorescence cells were rinsed with water sample before analyses. Following Coble (1996), the Ex/Em wavelengths used for the single point measurements were: Ex/Em $320 \mathrm{~nm} / 410 \mathrm{~nm}$ (peak-M) and Ex/Em $340 \mathrm{~nm} / 440 \mathrm{~nm}$ (peak-C) as indicators of marine and terrestrial humiclike substances, respectively. Fluorescence intensities were expressed in quinine sulfate units (QSU) by calibrating the instrument at Ex/Em: $350 \mathrm{~nm} / 450$ $\mathrm{nm}$ against a quinine sulfate dehydrate standard made up in $0.05 \mathrm{~mol} \mathrm{~L}^{-1}$ sulfuric acid.

\section{3. - Meteorological data}

Precipitation was recorded in a meteorological station supported by the Spanish Agencia Estatal de Meteorología (AEMET) located at the seafront of L'Estartit (0 $\mathrm{m}$ above sea level, Figure 1). To avoid interferences from buildings, wind data was recorded in a different meteorological station (also supported by AEMET) situated on top of the Roca Maura (228 m above sea level, Figure 1).

\section{4. - Graphical tools}


Depth-profile plots were produced using the Ocean Data View 4.7.8 software (ODV, Schlitzer, 2017). Wind rose plots were drawn using the WRPLOT View ${ }^{\mathrm{TM}}$ 7.0 software (Lakes Environmental). All other plots were drawn using the Sigma Plot 11.0 software (Systat Software Inc.).

\section{5. - Statistical Analyses}

Statistical analyses were preceded by standard data exploration in order to define data distribution (i.e. normality), homogeneity of variance, independence of the data, among others (Zuur et al., 2010). All the considered explanatory variables were inspected through Kendall rank correlation analysis to avoid collinearity. The response variable (FDOM peak C-M Ratio) is a continuous non-negative variable, which prevented us to use General Lineal Models. Beside this, data measured at different depths and year are no independent. Thus, in order to determine the role of the monitored environmental variables over the dynamics of the FDOM peak-C/peak-M Ratio, a Generalized Additive Mixed Model (GAMM) was fitted using the "mgcv" package for R (Wood, 2006). The model formulation incorporated a "gamma" error family distribution with a log-link function (avoiding fitting negative values). Non-independence of the data was taken into account by incorporating a random structure (depth and year as random intercept) inside the model (Zuur et al., 2009, 2016). Wind data was decomposed in its meridional and zonal components, in order to include circular data in statistical models. The optimal model was achieved following a backward selection criteria until all the remaining explanatory variables were significant. Also, Akaike's information Criteria (AIC) and residual inspection were used to determine the best model fitted. All the statistical analyses were supervised by OneMind-DataScience Ltd (www.onemind-datascience.com).

\section{3.- Results}

\section{1. - Physical properties}

\subsection{1. - Temperature}

The sampling resolution (for both depth and time) was higher for temperature than for any other measured variable as we included the data from the regular EOS Temperature Monitoring Program. In general, stratification of the water column was detected from May to October/November (Figure 2a). The 'reflux 
arrow' symbols (Figure 2) mark periods of vertical mixing, exhibiting the presence of a water mass of uniform temperature from December to April. During these periods, the temperature in the water column was the coldest, ranging from 12 to $14{ }^{\circ} \mathrm{C}$. Later, after spring, following the increase of daylight hours and air temperature, seawater became progressively warmer at surface, decreasing the density of the upper water layers and thus stratifying the water column. From early May to the end of June, water temperature increased up to more than $20^{\circ} \mathrm{C}$ and a strong thermocline was established at around $40-50 \mathrm{~m}$ depth in the four monitored years. The summer period (from mid-June to midSeptember) exhibited surface temperatures higher than $23^{\circ} \mathrm{C}$. During this season, rapid intrusions of cold water from deeper layers were detected, mainly during the months of July and August ('up arrow' symbols; Figure 2). Water stratification lasted until the end of October while surface was progressively cooling. From then onwards, the whole water column presented a homogeneous temperature of around $17.5^{\circ} \mathrm{C}$, decreasing to below $15^{\circ} \mathrm{C}$ at the end of November in 2012 and 2013, or later in 2011 and 2014.

\subsection{2. - Salinity}

In contrast to temperature, the only seasonal feature regarding salinity was the presence of low values (<37.5) in the upper layer during spring (Figure $2 b$ ). However, the intensity, duration and vertical extent of these spring episodes presented high inter-annual variability. For instance, low salinity waters reached the deepest sampled level (80 m) in March-April 2011, and in 2013, the episode extended to mid-summer (July-September). Highest salinity values $(>38)$, typically restricted to the deepest layer, were more frequent in mid-summer. Interestingly in 2012, high salinity values occurred along the whole water column and almost year-round.

\section{2. - Inorganic nutrients}

\subsection{1. - Nitrate}

Nitrate concentrations ranged from 0.25 to $6.00 \mu \mathrm{mol} \mathrm{L}^{-1}$ during the 4-year sampling period (Figure 2c). High levels of nitrate were mainly present when temperatures were lower than $15^{\circ} \mathrm{C}$ (during the winter season). From January to March, nitrate concentrations were always higher than $1.00 \mu \mathrm{mol} \mathrm{L}^{-1}$ in the 
entire water column. Each year, when temperature increased and the stratification progressed (spring season), nitrate concentrations decreased in surface waters $(<20 \mathrm{~m})$. The lowest levels of nitrate were detected in summer in surface waters $\left(\sim 0.25 \mu \mathrm{mol} \mathrm{L^{-1 }}\right)$, while at $20 \mathrm{~m}$, the concentration varied

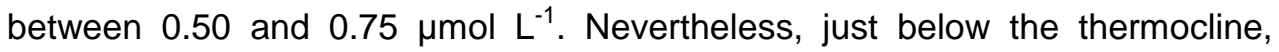
concentrations were always higher than $1.25 \mu \mathrm{mol} \mathrm{L}^{-1}$. Furthermore, the rapid deep-water intrusions in summer periods described above left a signature in the nitrate distribution. In particular, the more conspicuous one was that of 2012 , with concentrations ranging from 3 to $5 \mu \mathrm{mol} \mathrm{L} \mathrm{L}^{-1}$ at 50 and $80 \mathrm{~m}$ deep. During autumn, values remained in the $0.50-1.00 \mu \mathrm{mol} \mathrm{L}^{-1}$ range at surface, but below $20 \mathrm{~m}$ the concentrations increased. At $80 \mathrm{~m}$, concentrations were higher than $1.0 \mu \mathrm{mol} \mathrm{L}{ }^{-1}$ during the entire year, except for the autumn season in 2014.

\subsection{2. - Phosphate}

The variability of phosphate concentrations followed a pattern similar to that of nitrate (Figure $2 \mathrm{~d}$ ). Concentrations fluctuated between 0.05 and $0.25 \mu \mathrm{mol} \mathrm{L}^{-1}$ in the water column all year long. In general, increases in salinity were accompanied by higher concentrations of phosphate (winter-summer 2012 and summer-autumn 2013).

\subsection{3. - Silicate}

Silicate concentrations (Figure 2e) also followed a distribution comparable to nitrate (Figure 2c). Values in the water column during the four-year program ranged from 0.05 up to $5.00 \mu \mathrm{mol} \mathrm{L}^{-1}$. In a similar way as the phosphate data, high concentrations were mainly found in winter-summer 2012 and in summerautumn 2013.

\section{3. - Biotic variables}

\subsection{1. - Chlorophyll a}

Phytoplankton bloom periods, manifested by Chl a increases, were observed at the end of autumn and in spring, coinciding with the end of the winter mixing period (Figure 3a). During the spring blooms, Chl a concentrations reached values between 1.0 and $1.4 \mu \mathrm{L}^{-1}$. In general, during the summer periods, Chl a values at shallow layers $\left(<20 \mathrm{~m}\right.$ ) were lower than $0.2 \mu \mathrm{g} \mathrm{L}^{-1}$, in accordance with 
the lack of inorganic nutrients. Below $50 \mathrm{~m}, \mathrm{Chl}$ a concentrations were always lower than $0.6 \mu \mathrm{g} \mathrm{L}^{-1}$, except for the spring bloom episode of 2012 and 2013.

\subsection{2. - DOC}

The DOC distribution showed no clear patterns during the study period. Generally, DOC accumulations were frequently detected at the end of each summer in the shallow layers ( $<20 \mathrm{~m}$; Figure $3 \mathrm{~b}$ ). In these cases, DOC values ranged from 77 to $110 \mu \mathrm{mol} \mathrm{L}{ }^{-1}$. In winter 2012, an increase in DOC concentration was observed through the whole water column, reaching values of about $120 \mu \mathrm{mol} \mathrm{L}^{-1}$. During the spring season, a decrease was generally observed in the entire water column over the four monitored years. Furthermore, large DOC concentrations ( $\left.>90 \mu \mathrm{mol} \mathrm{L}^{-1}\right)$ were observed in the deeper depth in many of the sampling dates.

\section{4. - Optically-active DOM fractions}

\subsection{1. - Humic-like compounds}

Figure 4 presents the ratio between the terrestrial (peak-C) and marine (peak$M)$ humic-like substances compared with salinity values. In general, in surface waters the ratio peak $\mathrm{C}$ to peak $\mathrm{M}$ increased when salinity decreased. Overall, seasonal trends were not distinguished, yet it appears that increases in salinity coincided with decreases of this ratio. Thus, episodes of high-salinity water intrusions tend to coincide with low peak-C/peak-M ratios, pointing to the influence of bottom waters, with likely larger presence of marine humic-like substances. Fluctuations in salinity and peak-C/peak-M ratio were of higher magnitude in the shallower layers ( $<20 \mathrm{~m}$ deep). A remarkable feature was detected in August 2013 at the surface, when both salinity and the peak$\mathrm{C} /$ peak-M ratio decreased. Salinity decreased likely because a raining event occurred prior the sampling day (Figure 8), while the decrease of peak-C/peak$\mathrm{M}$ ratio along the whole water column was consistent with the intrusion of deep water into surface (Figure 4).

\subsection{2. - FDOM dynamics and the role of environmental variables}

Collinearity analysis showed that only nitrate and silicate showed a significant even low (rho $=0.6)$ correlation and by this, silicate was no longer considered in 
statistical modelling. From the backward selection criteria the variables that significantly explained FDOM peak C-M dynamics were wind (zonal component; $F=3.247, p$-value $<0.05)$ and precipitation $(F=14.461, p$-value $<0.01)$. The meridional component of wind, even not significant $(F=2.901$, $p$-value $=0.09)$ it was kept in the model as improved the residuals validation (FIGX). The model explained almost $30 \%$ of variability and the partial effects of environmental variables over the FDOM variability can be seen in fig. YY.

\section{4. - Discussion}

\section{1. - Environmental parameters and wind forcing}

Winter temperatures at EOS over the monitored years (2011-2014) were around $12-13^{\circ} \mathrm{C}$, comparable to the average surface temperatures registered in the NW Mediterranean (Durrieu de Madron et al., 2011). However, 2014 was particularly warm, being the warmest year of the study period, during which temperatures remained always above the average temperature of the last forty years. Although our studied period is too short to discuss long-time trends, Coma et al. (2009) reported that the temperature of the whole water column at this sampling station had been steadily increasing since 1974, and a similar pattern was observed in other NW Mediterranean stations such as the DYFAMED station, from 1995 to 2007 (Marty and Chiavérini, 2010) or the SOLA (coastal) and MOLA (oceanic) stations (Banyuls-sur-mer, SE France; Sánchez-Pérez, 2015).

During the 4-year studied period, some of the phytoplankton bloom episodes (as shown by the high values of $\mathrm{Chl}$ a) were associated to surface salinity minima (Figure $3 \mathrm{a}$ and Figure $4 \mathrm{a}$ ), likely linked to heavy rain and/or important river runoff. Similar episodes were also reported in the vicinity of EOS such as in the bay of Blanes (50 km to the south) by Guadayol et al. (2009) and Romera-Castillo et al. (2013) and in the bay of Banyuls-sur-mer (50 km to the north of EOS) by Sánchez-Pérez (2015). During the stratified season, the concentrations of nitrate and phosphate at EOS were $\sim 0.3 \mu \mathrm{mol} \mathrm{L}{ }^{-1}$ and 0.03 $\mu \mathrm{mol} \mathrm{L} \mathrm{L}^{-1}$, respectively, analogous to the concentrations observed by Gasol et al.

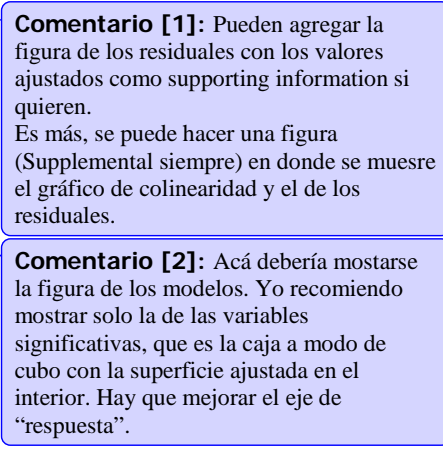

Comentario [2]: Acá debería mostarse la figura de los modelos. Yo recomiendo mostrar solo la de las variables significativas, que es la caja a modo de cubo con la superficie ajustada en el interior. Hay que mejorar el eje de "respuesta". 
(2012) and Romera-Castillo et al. (2013) in the bay of Blanes, mentioned above.

Following the typical wind patterns in the region (Salat, 1996; Guadayol et al., 2006), from late autumn to the end of winter, dominant winds at EOS were from the $\mathrm{N}$ and NW, whereas winds from the S and SW were more common in spring and summer (Figure 5). The rectangles marked as \#1, \#2, \#3 and \#4 in Figure 4 represent four of the typical events detected at EOS from 2011 to 2014 based on intense wind features (wind speed $>4 \mathrm{~m} / \mathrm{s}$ during $>50 \%$ of the 4 -day period before the sampling date; Figure 6), which altered the vertical distribution of the studied variables. Generally, during the 4-year monitoring program, when Tramuntana (N-NW) winds predominated (Figure 6a, b, e, f), the water column was well mixed (Figure $2 \mathrm{a}$, wind scenario $\# 1$ ) or only slightly stratified (Figure $2 \mathrm{a}$, wind scenario \#4). On the contrary, during the warmer months of the year, when the water column was highly stratified, Garbí (S-SW) winds used to prevail (Figure 2a, wind episodes \#2 and \#3; Figure $6 \mathrm{c}, \mathrm{d}$ ). The role of these two different winds on the local water movement, according to the Ekman theory (see Sverdrup et al., 1942) is depicted in Figure 7. Under Tramuntana regime, water is transported towards the coastline where it tends to accumulate and sink (Figure 7a), while under Garbí regime water is transported offshore causing the upwelling of cold oceanic water (Figure $7 b$ ), as clearly shown in summer 2011 (Figure 2a).

\section{2. - Biogeochemical variables and influence of precipitation events}

As defined by Coble (1996) and also identified in other studies (Nieto-Cid et al., 2006; Lønborg et al., 2010; Romera-Castillo et al., 2011b, 2013), peak-M is associated, in general, with humic-like compounds produced in situ, mainly as by-products of prokaryote metabolism. On the other hand, peak- $C$ has been defined as a tracer of humic-substances of terrestrial origin (Coble, 1996). Therefore, the proportion of peak-C with respect to peak-M fluorescence could be used as a tracer of the terrestrial vs marine origin of the DOM. During upwelling events, increases in salinity coincided with decreases in the peak$\mathrm{C} /$ peak-M ratio, indicating a higher proportion of FDOM produced in situ, probably at the deep layers (Figure 4). This possibility is supported by the 
occurrence of higher proportions of high nucleic acid (HNA) prokaryotes in relation to the total abundance during the upwelling events (data from EOS Biological Sampling Program), which tend to be associated to higher activity (Bouvier et al., 2007).

Concentrations of DOC and FDOM in coastal areas are usually strongly influenced by terrestrially-derived inputs related to rain events and river drainage (Romera-Castillo et al., 2013; Sánchez-Pérez, 2015). At EOS, we attribute changes in the quality of FDOM (ratio peak-C/peak-M) mainly to rain events. In general, storms were sporadic and did not show any annuallyrepeated pattern (Figure 8). We presume that the presence of the Ter river mouth, located southwards, did not influence the seawater properties at the sampling station mainly because of the direction of the Liguro-Provençal current, which flows from north to south. However, we observed DOC accumulation in surface waters by the end of summer (Figure 3). This accumulation is directly linked to the practically-complete depletion of inorganic nutrients that limit microbial growth (Thingstad et al., 1997; Goutx et al., 2009; Tedetti et al., 2012; Romera-Castillo et al., 2013).

Moreover, comparing rain episodes and sampling dates, we observed that only a few samplings were carried out just 1-3 days after significant precipitation events (Figure 8): November 2011, May and October 2012, July 2013, and May and October 2014. Nevertheless, if we take a look at Figure 7, under strong southerly winds we would see the influence of deep waters at the surface, while under northerly winds we would observe continental waters confined towards the coast. Thus, the way these rain events influenced the water column during these events was conditioned by the actual wind regime occurring at each sampling, as follows:

- On October 2012, we observed a precipitation event just before the sampling day (Figure 8) but salinity values were high and the peak-C/peak-M ratio exhibited a minimum (Figure 4a). Despite the observed rainfall, the dominance of southerly winds during these days (Figure $5 b$ ), promoted the upwelling of waters from deeper layers. 
481

- Conversely, during rain events in November 2011, May 2012 and October 2014 (Figure 8), low salinity values were detected at the surface, complemented with high peak-C/peak-M ratios (Figure $4 \mathrm{a}$ ). Weak and very variable winds were dominant during these periods (Figure 5) causing the occurrence of continental waters at the EOS site, enhancing the terrestrial signature of the DOM.

- Relatively low salinity values were also found at the surface in July 2013 and May 2014 (Figure 4a), following the corresponding rain events (Figure 8). However, these salinity minimums were associated to sharp decreases of the peak-C/peak-M ratios (Figure $4 a$ ). These two periods were dominated by stronger and variable winds with a strong southerly component (Figure 5), which boosted the surge of deep water with an oceanic DOM signature. Nevertheless, the strong variability of the winds led to detectable low salinity values in the station.

\section{3. - DOM transformations at EOS and implications in the global carbon} cycle

Several authors have pointed out different hypotheses to explain the reduced DOM remineralization in deep waters, proposing that the low DOM concentration and the recalcitrant character of the organic material are key factors controlling this reduction (Arrieta et al., 2015; Dittmar, 2015). Yet, during upwelling events, deep-water meets surface layers of the ocean where the lability and the concentration of DOM are, generally, higher.

At surface layers, the arrival of waters from the deeper strata (with relatively high proportion of recalcitrant material) is recurrent. This phenomenon was associated with strong winds blowing from the S-SW. Unfortunately, our sampling frequency did not allow us to follow the subsequent transformations of the raised water. However, in the light of the results discussed here, it is plausible that the availability of fresh labile carbon, as a result of photosynthesis activities, together with the light exposure in surface waters, would favor the remineralization of some of the highly refractory organic compounds from the upwelled waters. Thus, indicating that depending on the wind regime, a malfunctioning of the MCP can take place at EOS. 


\section{5. - Conclusions}

Compared to the nearby sampling sites of Blanes Bay (50 km to the South) and Banyuls-sur-mer (50 $\mathrm{km}$ to the North), the high interannual environmental variability found at EOS highlights a main difference regarding DOM dynamics: At this location, land-derived inputs had a low influence in controlling the dynamics of DOM, whereas it was the interaction with deeper upwelled waters what played the most important role in determining the variations of the humiclike DOM. Unfortunately, we did not sample along a perpendicular transect to the coast, which would have been useful to corroborate this statement.

In summer, when the water column was highly stratified, S-SW winds displaced surface waters off the coast promoting upwelling processes. In this study, these upwelling episodes were identified as one of the mechanisms providing a surplus of humic-like material and inorganic nutrients from deep waters. In a related way, during winter, strong Tramuntana winds favored the movement of surface water towards the coast, promoting the homogenization of the entire water column. The results obtained indicate that depending on the predominant winds in this area, EOS can act as a sink of humic-like material or as a source when the remineralization processes are taking place. This study underscores the importance of sampling at several depths in the water column and emphasizes the need for increasing the sampling frequency (e.g. from monthly to weekly periods) to further understand the coupling between environmental variables and the meteorological features, especially to assess the effect of rain events.

\section{Acknowledgements}

The EOS Monitoring Program is supported by the Institut de Ciències del Mar (ICM-CSIC) and the Parc Natural del Montgrí, les Illes Medes i el Baix Ter (Generalitat de Catalunya). We would like to thank Vanessa Balagué and Mara Abad for performing $\mathrm{Chl}$ a measurements and inorganic nutrient and TOC analyses, respectively. Also, Estela Romero for her help with graphs edition. The continuity of the sampling program has been possible thanks to the funding of projects: ECOSER (CTM2011-15937-E), DOREMI (CTM2012-342949), SUAVE (CTM2014/23456/1) and ANIMA (CTM2015-65720) from the Spanish 
Ministerio de Economía y Competitividad (MINECO) and the Grup de Recerca Consolidat 2014SGR1179 and 2014SGR1029 financed by the Agència de Gestió d'Ajuts Universitaris i de Recerca (AGAUR) from the Generalitat de Catalunya. F.L.A. benefited from a JAE-pre pre-doctoral fellowship (JAEPre_2011_00923) from the Agencia Estatal Consejo Superior de Investigaciones Científicas (CSIC). M.N.-C. was funded by the project FERMIO (MINECO, CTM2014-57334-JIN) co-financed with FEDER funds.

\section{Bibliography}

Bolaños, R., Jordà, G., Cateura, J., Lopez, J., Puigdefàbregas, J., Gómez, J., Espino, M., 2009. The XIOM: 20 years of a regional coastal observatory in the Spanish Catalan coast. J. Mar. Syst. 77, 237-260. doi:10.1016/j.jmarsys.2007.12.018

Bouvier, T., Del Giorgio, P.A., Gasol, J.M., 2007. A comparative study of the cytometric characteristics of High and Low nucleic-acid bacterioplankton cells from different aquatic ecosystems. Environ. Microbiol. 9, 2050-2066. doi:10.1111/j.1462-2920.2007.01321.x

Chen, R.F., Bada, J.L., 1994. The fluorescence of dissolved organic matter in porewaters of marine sediments. Mar. Chem. 45, 31-42. doi:10.1016/03044203(94)90089-2

Cloern, J.E., Jassby, A.D., 2008. Complex seasonal patterns of primary producers at the land-sea interface. Ecol. Lett. 11, 1294-1303. doi:10.1111/j.1461-0248.2008.01244.x

Coble, P.G., 2007. Marine optical biogeochemistry: the chemistry of ocean color. Chem. Rev. 107, 402-418. doi:10.1021/cr050350+

Coble, P.G., 1996. Characterization of marine and terrestrial DOM in seawater using excitation-emission matrix spectroscopy. Mar. Chem. 51, 325-346. doi:10.1016/0304-4203(95)00062-3

Colacino, M., 1992. Mediterranean meteorology. In: H. Charnock (ed.): Winds and currents of the Mediterranean basin, Reports of Meteorology and Oceanography. Harvard University, 40: 1-38.

Coma, R., Ribes, M., Serrano, E., Jiménez, E., Salat, J., Pascual, J., 2009. Global warming-enhanced stratification and mass mortality events in the Mediterranean. Proc. Natl. Acad. Sci. 106, 6176-6181. doi:10.1073/pnas.0805801106 
Durrieu de Madron, X., Guieu, C., Sempéré, R., Conan, P., Cossa, D. D'Ortenzio, F., Estournel, C., Gazeau, F., Rabouille, C., Stemmann, L., Bonnet, S., Diaz, F., Koubbi, P., Radakovitch, O., Babin, M., Baklouti, M., BanconMontigny, C., Belviso, S., Bensoussan, N., Bonsang, B., Bouloubassi, I., Brunet C., Cadiou, J.F., Carlotti, F., Chami, M., Charmasson, S., Charrière, B., Dachs, J., Doxaran, D., Dutay, J.C., Elbaz-Poulichet, F., Eléaume, M., Eyrolles, F., Fernández, C., Fowler, S., Francour, P., Gaertner, J.C., Galzin, R., Gasparini, S., Ghiglione, J.F., González, J.L., Goyet, C., Guidi, L., Guizien, K., Heimbürger, L.-E., Jacquet, S.H.M., Jeffrey, W.H., Joux, F., Le Hir, P., Leblanc, K., Lefèvre, D., Lejeusne, C., Lemée, R., Loÿe-Pilot, M.D., Mallet, M., Méjanelle, L., Mélin, F., Mellon, C., Mérigot, B., Merle, P.L., Migon, C., Miller, W.L., Mortier, L., Mostajir, B., Mousseau, L., Moutin, T., Para, J., Pérez, T., Petrenko, A., Poggiale, J.C., Prieur, L., Pujo-Pay, M., Raimbault, P., Rees, A.P., Ridame, C., Rontani, J.F., Ruiz Pino, D., Sicre, M.A., Taillandier, V., Tamburini, C., Tanaka, T., Taupier-Letage, I., Tedetti, M., Testor, P., Thébault, H., Thouvenin, B., Touratier, F., Tronczynski, J., Ulses, C., Van Wambeke, F., Vantrepotte, V., Vaz, S., Verney, R., 2011. Marine ecosystems' responses to climatic and anthropogenic forcings in the Mediterranean. Prog. Oceanogr. 91, 97-166. doi:10.1016/j.pocean.2011.02.003

Flamant, C., Pelon, J., Hauser, D., Quentin, C., Drennan, W.M., Gohin, F., Chapron, B., Gourrion, J., 2003. Analysis of surface wind and roughness length evolution with fetch using a combination of airborne lidar and radar measurements. J. Geophys. Res. 108, 1-26. doi:10.1029/2002JC001405

Gasol, J.M., Massana, R., Simó, R., Marrasé, C., Acinas, S.G., Pedrós-Alió, C. Pelejero, C., Calvo, E., Vaqué, D., Peters, F., 2012. Blanes Bay (Site 55). In ICES Phytoplankton and Microbial Ecology Status Report 2010/2012., edited by T.D. O'Brien, W.K.W. Li, and X.A.G. Morán, 138-41. ICES Cooperatie Research Report.

Goutx, M., Guigue, C., Aritio, D., Ghiglione, J.F., Pujo-Pay, M., Raybaud, V., Duflos, M., Prieur, L., 2009. Short term summer to autumn variability of dissolved lipid classes in the Ligurian sea (NW Mediterranean). Biogeosciences 6, 1229-1246.

Grifoll, M., Aretxabaleta, A.L., Pelegrí, J.L., Espino, M., Warner, J.C., SánchezArcilla, A., 2013. Seasonal circulation over the Catalan inner-shelf (northwest Mediterranean Sea). J. Geophys. Res. Ocean. 118, 5844-5857. doi:10.1002/jgrc.20403

Guadayol, Ò., Peters, F., Marrasé, C., Gasol, J.M., Roldán, C., Berdalet, E., Massana, R., Sabata, A., 2009. Episodic meteorological and nutrient-load events as drivers of coastal planktonic ecosystem dynamics: A time-series analysis. Mar. Ecol. Prog. Ser. 381, 139-155. doi:10.3354/meps07939

Hansell, D.A., Carlson, C.A., Repeta, D.J., Schlitzer, R., 2009. Dissolved Organic Matter in the Ocean. A controversy stimulates new insights. Oceanography 22, 202-211. 
Hansen, H.P. and Grasshoff, K. (1983). Automatic chemical analysis. In: Methods of Seawater Analysis. Verlag Chemie, Weinheim, pp. 368-376.

Hopkins, T.S., 1978. Physical processes in the Mediterranean basins. In: B. Kjerfve (ed.): Estuarine transport processes. Univ. of South Carolina Press: 269-310.

Jiao, N., Herndl, G.J., Hansell, D.A., Benner, R., Kattner, G., Wilhelm, S.W., Kirchman, D.L., Weinbauer, M.G., Luo, T., Chen, F., Azam, F., 2010. Microbial production of recalcitrant dissolved organic matter: long-term carbon storage in the global ocean. Nat. Rev. Microbiol. 8, 593-599. doi:10.1038/nrmicro2386

López-García, M.J., Millot, C., Font, J., García-Ladona, E., 1994. Surface Circulation Variability in the Balearic Basin. Journal of Geophysical Research 99 (C2): 3285-96.

Lønborg, C., Álvarez-Salgado, X.A., Davidson, K., Martínez-García, S., Teira, E., 2010. Assessing the microbial bioavailability and degradation rate constants of dissolved organic matter by fluorescence spectroscopy in the coastal upwelling system of the Ría de Vigo. Mar. Chem. 119, 121-129. doi:10.1016/j.marchem.2010.02.001

Margalef, R., 1969. Composición específica del fitoplancton de la costa catalano-levantina (Mediterráneo occidental) en 1962-1967. Investig. Pesq. 33, 345-380.

Marty, J.C., Chiavérini, J., 2010. Hydrological changes in the Ligurian Sea (NW Mediterranean, DYFAMED site) during 1995-2007 and biogeochemical consequences. Biogeosciences 7, 2117-2128. doi:10.5194/bg-7-2117-2010

Millot, C., 1979. Wind induced upwellings in the Gulf of Lions. Oceanol. Acta 2, 261-274.

Millot, C., Taupier-Letage, I., 2005. Circulation in the Mediterranean Sea. Environ. Chem. 5, 29-66. doi:10.1007/b107143

Murphy, K.R., Stedmon, C.A., Waite, T.D., Ruiz, G.M., 2008. Distinguishing between terrestrial and autochthonous organic matter sources in marine environments using fluorescence spectroscopy. Mar. Chem. 108, 40-58. doi:10.1016/j.marchem.2007.10.003

Nieto-Cid, M., Álvarez-Salgado, X.A., Gago, J., Pérez, F.F., 2005. DOM fluorescence, a tracer for biogeochemical processes in a coastal upwelling system (NW Iberian Peninsula). Mar. Ecol. Prog. Ser. 297, 33-50. doi:10.3354/meps297033

Nieto-Cid, M., Álvarez-Salgado, X.A., Pérez, F.F., 2006. Microbial and photochemical reactivity of fluorescent dissolved organic matter in a coastal upwelling system. Limnol. Oceanogr. 51, 1391-1400. doi:Retrieved from http://www.jstor.org/stable/3841185 
Para, J., Coble, P.G., Charrière, B., Tedetti, M., Fontana, C., Sempéré, R., 2010. Fluorescence and absorption properties of chromophoric dissolved organic matter (CDOM) in coastal surface waters of the northwestern Mediterranean Sea, influence of the Rhône River. Biogeosciences 7, 40834103. doi:10.5194/bg-7-4083-2010

Pey, J., Pérez, N., Querol, X., Alastuey, A., Cusack, M., Reche, C., 2010. Intense winter atmospheric pollution episodes affecting the Western Mediterranean. Sci. Total Environ. 408, 1951-1959. doi:10.1016/j.scitotenv.2010.01.052

Robinson, R.A., Leslie, W.G., Theocharis, A., Lascaratos, A., 2001. Mediterranean Sea Circulation. Ocean Curr. 1-19. doi:10.1006/rwos.2001.0376

Romera-Castillo, C., Álvarez-Salgado, X.A., Galí, M., Gasol, J.M., Marrasé, C., 2013. Combined effect of light exposure and microbial activity on distinct dissolved organic matter pools. A seasonal field study in an oligotrophic coastal system (Blanes Bay, NW Mediterranean). Mar. Chem. 148, 44-51. doi:10.1016/j.marchem.2012.10.004

Romera-Castillo, C., Nieto-Cid, M., Castro, C.G., Marrasé, C., Largier, J., Barton, E.D., Álvarez-Salgado, X.A., 2011a. Fluorescence: Absorption coefficient ratio - Tracing photochemical and microbial degradation processes affecting coloured dissolved organic matter in a coastal system. Mar. Chem. 125, 26-38. doi:10.1016/j.marchem.2011.02.001

Romera-Castillo, C., Sarmento, H., Álvarez-Salgado, X.A., Gasol, J.M., Marrasé, C., 2011b. Net production and consumption of fluorescent colored dissolved organic matter by natural bacterial assemblages growing on marine phytoplankton exudates. Appl. Environ. Microbiol. 77, 7490-7498. doi:10.1128/AEM.00200-11

Romera-Castillo, C., Sarmento, H., Álvarez-Salgado, X.A., Gasol, J.M., Marrasé, C., 2010. Production of chromophoric dissolved organic matter by marine phytoplankton. Limnol. Oceanogr. 55, 446-454.

Salat, J., Font, J., 1987. Water mass structure near and offshore the Catalan Sea during winters of 1982 and 1983. Annales Geophysicae, 5B (1): 49-54.

Salat, J., 1996. Review of Hydrographic Environmental Factors That May Influence Anchovy Habitats in Northwestern Mediterranean. Scientia Marina 60 (S2): 21-32.

Salat J., Pascual, J., 2002. The oceanographic and meteorological station at I'Estartit (NW Mediterranean). CIESM Workshop Series, 16: 29-32.

Sánchez-Pérez, E.D., 2015. The role of abiotic and biotic mechanisms controlling the dynamics of the dissolved organic matter in pelagic ecosystems (NW Mediterranean). Université Pierre et Marie Curie.

Sánchez-Pérez, E.D., Marín, I., Nunes, S., Aparicio, F.L., Fernández-González, L., Peters, F., Pujo-Pay, M., Conan, P., Marrasé, C., 2016. Aerosol inputs affect 
the optical signatures of dissolved organic matter in NW Mediterranean coastal waters. Sci. Mar. 80, 437-446. doi:10.3989/scimar.04318.20B

Santinelli, C., 2015. DOC in the Mediterranean Sea, in: Hansell, D.A., Carlson, C.A. (Eds.), Biogeochemistry of Marine Dissolved Organic Matter. Elsevier Inc., pp. 579-608. doi:10.1016/B978-0-12-405940-5.00013-3

Schlitzer, R. (2017). Ocean Data View. Available online at: http://odv.awi.de

Schroeder, K., Josey, S.A., Herrmann, M., Grignon, L., Gasparini, G.P., Bryden, H.L., 2010. Abrupt warming and salting of the Western Mediterranean Deep Water after 2005: Atmospheric forcings and lateral advection. J. Geophys. Res. Ocean. 115, 1-18. doi:10.1029/2009JC005749

Sverdrup, H. U., Johnson, M. W., Fleming, R. H., 1942. The oceans. PrenticeHall, Englewood Cliffs

Tedetti, M., Longhitano, B.R., García, A.N., Guigue, A.C., 2012. Fluorescence properties of dissolved organic matter in coastal Mediterranean waters influenced by a municipal sewage effluent (Bay of Marseilles, France). Environ. Chem. 9, 438-449.

Thingstad, T.F., Hagström, Å., Rassoulzadegan, F., 1997. Accumulation of degradable DOC in surface waters: Is it caused by a malfunctioning microbial loop? Limnol. Oceanogr. 42, 398-404. doi:10.4319/lo.1997.42.2.0398

Turner, J.T., 2015. Zooplankton fecal pellets, marine snow, phytodetritus and the ocean's biological pump. Prog. Oceanogr. 130, 205-248. doi:10.1016/j.pocean.2014.08.005

Vila-Reixach, G., Gasol, J.M., Cardelús, C., Vidal, M., 2012. Seasonal dynamics and net production of dissolved organic carbon in an oligotrophic coastal environment. Mar. Ecol. Prog. Ser. 456, 7-19. doi:10.3354/meps09677

Wada, S., Omori, Y., Kayamyo, Y., Tashiro, Y., Hama, T., 2015. Photoreactivity of dissolved organic matter from macroalgae. Reg. Stud. Mar. Sci. 2, 12-18. doi:10.1016/j.rsma.2015.08.018

Wood, S.N., 2006. Generalized Additive Models. An introduction with R. Chapman and Hall/CRC.

Yentsch, C.S. and Menzel, D.W., 1963. A method for the determination of phytoplankton chlorophyll and phaeophytin by fluorescence. Deep-Sea Res. 10, 221-231.

Zuur, A.F., leno, E.N., Walker, N.J., Saveliev, A.A., Smith, G.M., 2009. Mixed Effects Models and Extensions in Ecology with R. Springer, New York, NY. 574 pp.

Zuur, A.F., leno, E.N., Elphick, C.S., 2010. A protocol for data exploration to avoid common statistical problems. Methods in Ecology and Evolution 1: 3-14, http://doi.wiley.com/10.1111/j.2041-210X.2009.00001.x 
Zuur, A.F. and leno, E.N., 2016. A protocol for conducting and presenting results of regression-type analyses. Methods in Ecology and Evolution 7: 636645, http://doi.wiley.com/10.1111/2041-210X.12577

\section{Figure captions}

Figure 1. Map of the study area. L'Estartit Oceanographic Station (EOS) is represented by a black circle.

Figure 2. Water column distribution of a) temperature $\left({ }^{\circ} \mathrm{C}\right)$, b) salinity, c) nitrate $\left.\left(\mu \mathrm{mol} \mathrm{L}{ }^{-1}\right), d\right)$ phosphate $\left(\mu \mathrm{mol} \mathrm{L}^{-1}\right)$ and e) silicate concentrations $\left(\mu \mathrm{mol} \mathrm{L}^{-1}\right)$ from January 2011 to December 2014. The black dots represent sampling points. Temperature measurements were performed every 3 days. Blank spaces represent periods when the weather conditions did not allow sampling. The 'reflux arrow' symbols in the bottom of the plots indicate processes of vertical mixing in the whole water column whereas the 'up arrow' symbols indicate the presence of upwelling processes. The plots were drawn using the software Ocean Data View (Schlitzer, 2017).

Figure 3. Water column distribution of a) chlorophyll $a$ (in $\mu \mathrm{g} \mathrm{L}^{-1}$ ) and b) DOC (in $\mu \mathrm{mol} \mathrm{L}^{-1}$ ) during the 4-year study period. The 'reflux arrow' and 'up arrow' symbols below the plots represent processes of vertical mixing and upwelling events, respectively. The plots were drawn using the software Ocean Data View (Schlitzer, 2017).

Figure 4. Overlayed plots of salinity (black dots) and the peak- $\mathrm{C}$ to peak-M ratio (white dots) at a) $0.5 \mathrm{~m}$, b) $20 \mathrm{~m}, \mathrm{c}$ ) $50 \mathrm{~m}$ and d) $80 \mathrm{~m}$ depth during the fouryear study period. The blue rectangles indicate the occurrence of different wind events (see text). The 'reflux arrow' and 'up arrow' symbols below the plots represent processes of vertical mixing and upwelling events, respectively.

Figure 5. Wind velocity and direction feather plots: a) 2011, b) 2012, c) 2013 and d) 2014. Southerly winds are positive and northerly winds negative. Arrow lengths indicate the wind speed. The grey vertical lines represent sampling dates.

Figure 6. Wind rose plots (direction and intensity) of winds at the study site representing the 4-day period before the sampling of: a) January 2012 (part of event \#1), b) February 2012 (part of event \#1), c) July 2012 (event \#2), d) July 2013 (event \#3), e) September 2012 (part of event \#4) and f) October 2013 (part of event \#4). The resultant vector of the average wind direction is also indicated. Colour scales represent wind speeds in $\mathrm{m} \mathrm{s}^{-1}$. The 'reflux arrow' and 'up arrow' symbols indicate the occurrence of vertical mixing of the water column or an upwelling event.

Figure 7. Representation of the northern Catalan coast under a) "Tramuntana" wind regime (northerlies) and b) S-SW winds. Black arrows represent wind 
789 direction and white arrows indicate the displacement of surface seawater due to 790 Ekman transport (Coriolis effect). The EOS location is indicated.

Figure 8. L'Estartit village daily precipitation (mm) of: a) 2011, b) 2012, c) 2013 and d) 2014. The grey vertical lines indicate sampling dates. 